\title{
Seroprevalensi Penyakit Avian Influenza Subtipe H5N1 pada Ayam Buras di Pasar Beringkit dan Galiran, Bali
}

\section{Seroprevalence of Avian Influenza H5n1 Subtype of Free Range Chicken in Beringkit dan Galiran Markets, Bali}

\author{
Baiq Indah Pratiwi ${ }^{1}$, Gusti Ayu Yuniati Kencana ${ }^{2 *}$, I Nyoman Suartha ${ }^{3}$ \\ ${ }^{1}$ Fakultas Kedokteran Hewan, Universitas Udayana, Bali \\ ${ }^{2}$ Laboratorium Virologi Veteriner, Fakultas Kedokteran Hewan, Universitas Udayana, Bali \\ ${ }^{3}$ Laboratorium Ilmu Penyakit Dalam, Fakultas Kedokteran Hewan, Universitas Udayana, Bali \\ *Email: yuniati_kencana@unud.ac.id
}

Naskah diterima: 22 Februari 2020, direvisi: 22 Mei 2020, disetujui: 10 Agustus 2020

\begin{abstract}
Avian Influenza (AI) is a strategic communicable and zoonotic disease caused by the Highly Pathogenic Avian Influenza (HPAI) subtype H5N1. The poultry market has important roles in the preservation, propagation, and spreads of the HPAI subtipe H5N1 virus from poultry to other species and humans-beings. The purpose of this study was to determine the level of seroprevalence of Avian Influenza (H5N1) in free-range chickens at the Beringkit and Galiran markets. A total of 120 free-range chicken serums from 2 markets, 60 from the Beringkit market and 60 from the Galiran market were used in this study. The retrieval period is 2 months and is taken every 2 weeks so there are 4 withdrawals. Chicken serum is taken from five selected traders who sell 6 to 10 free-range chickens. All samples were tested using Haemaglutination (HA) and Haemaglutination Inhibition (HI) tests at the Denpasar Veterinary Centre. The data titer of the antibodies obtained was analyzed by Non-Parametric Statistic Test Chi-Square $(\chi 2)$ using IBM SPSS for windows. The results of the study showed that seroprevalence of HPAI subtype H5N1 in both Beringkit and Galiran Markets were 3.3\% and 6.7\% respectively with seroprevalence in two markets of $5.0 \%$ which was statistically not significantly different $(\mathrm{P}<0.05)$. To prevent the transmissions of HPAI subtype H5N1 at the Beringkit market and Galiran it was recommended to do vaccination and more attantion to the market management and the free-range chicken maintenance system.
\end{abstract}

Key words: avian influenza (H5N1); Beringkit dan Galiran markets; free-range chicken; seroprevalence

\begin{abstract}
Abstrak
Avian Influenza (AI) merupakan penyakit menular srategis dan bersifat zoonosis disebabkan oleh virus Highly Pathogenic Avian Influenza (HPAI) subtipe H5N1. Pasar unggas memiliki peran penting dalam pelestarian, perbanyakan, dan penyebaran virus HPAI subtipe $\mathrm{H} 5 \mathrm{~N} 1$ dari unggas ke unggas lain dan manusia. Tujuan penelitian ini untuk mengetahui seroprevalensi penyakit Avian Influenza subtipe H5N1 pada ayam buras di Pasar Beringkit dan Galiran, Bali. Sebanyak 120 serum ayam buras dari 2 pasar, 60 dari pasar Beringkit dan 60 dari pasar Galiran digunakan dalam penelitian ini. Periode pengambilan selama 2 bulan dan diambil tiap 2 minggu sehingga ada 4 kali pengambilan. Serum ayam diambil dari lima orang pedagang terpilih yang menjual 6 sampai 10 ekor ayam buras. Pengujian sampel dilakukan di Balai Besar Veteriner Denpasar dengan uji Haemaglutinasi (HA) dan Hambatan Hemaglutinasi (HI). Data titer antibodi yang diperoleh dianalisis dengan Uji Statistik Non-Parametrik Chi- Square ( $\chi 2)$ menggunakan IBM SPSS for windows. Hasil penelitian menunjukkan bahwa seroprevalensi HPAI subtipe H5N1 di Pasar Beringkit sebesar 3,3\% dan Pasar Galiran sebesar 6,7\%, dengan seroprevalensi di kedua pasar sebesar 5,0\% yang secara statistik tidak berbeda nyata $(\mathrm{P}<0,05)$.
\end{abstract}

Kata kunci: ayam buras; avian influenza (H5N1); Pasar Beringkit dan Galiran; seroprevalensi 


\section{Pendahuluan}

Avian Influenza (AI) merupakan salah satu penyakit unggas menular strategis dan bersifat zoonosis dapat menimbulkan kematian baik pada hewan maupun manusia yang terinfeksi. Penyebab penyakit AI adalah virus Highly Pathogenic Avian Influenza (HPAI) subtipe H5N1 (Wright dan Webster, 2001). Ternak domestik termasuk ayam dan kalkun sangat rentan terhadap virus ini menimbulkan kematian (Kumala, 2005). Di Indonesia kasus AI pertama kali dilaporkan pada peternakan ayam ras komersial di Jawa, Lampung, Sumatera dan Kalimantan (Kandun, 2006). Di Bali kasus AI pertama kali dilaporkan pada ayam buras (Mahardika et al., 2004). Saat ini penyakit AI subtipe H5N1 sudah terkendali, tetapi perlu di waspadai dan kondisi penyakit perlu di deteksi secara berkala. Oleh karena itu surveillance terhadap AI perlu dilakukan di peternakan maupun di pasar.

Pasar unggas merupakan salah satu tempat yang berperan penting dalam pelestarian, perbanyakan, dan penyebaran virus AI dari unggas ke unggas lain(Leung et al., 2007) serta dari unggas ke manusia (Dinh et al., 2007). Penyebaran virus didukung oleh sistem perdagangan lokal di pasar unggas yang kurang memperhatikan manajemen pasar yang baik, sanitasi serta tata lokasi pasar unggas (Siahaan et al., 2014). Penularan AI dapat terjadi akibat mobilitas manusia yang membeli dan menjual unggas hidup serta produk asal unggas di pasar (Suartha et al., 2010).

Sebagian besar pasar unggas yang ada di Bali bercampur dengan pedagang pasar yang menjual kebutuhan sehari-hari seperti beras, sayur-sayuran, bumbu, buah-buahan, jajanan dan makanan yang telah matang. Unggas yang diperjual-belikan berasal dari peternakan intensif maupun peternakan rakyat (Suartha et al., 2010). Di pasar, unggas yang dijual berada dalam area yang sangat berdekatan. Kondisi tersebut mempermudah terjadinya penularan virus AI antar unggas (Nguyen et al., 2005). Kondisi pasar yang demikian memiliki resiko sangat tinggi bagi pengunjung pasar hewan karena secara tidak langsung dapat tertular dan pula sebagai sumber penyebar virus ke hewan lain (Susanti et al., 2008).

Pasar Beringkit dan Galiran merupakan pasar tradisional terbesar di Bali dan sangat ramai dikunjungi dengan aktifitas perdagangan hewan besar maupun perunggasan. Sumber unggas yang diperdagangkan di pasar Beringkit sebagian besar berasal dari Kabupaten Badung, Tabanan, Denpasar, dan Kabupaten Buleleng. Pasar Unggas Galiran mendapat suplai unggas dari Kabupaten Klungkung, Gianyar, Bangli, dan Karangasem (Hartawan, 2011; Putra et al., 2013). Sebanyak $76,1 \%$ menjual unggas berbagai umur dan jenis yang ditempatkan didalam satu keranjang besar (Suartha et al., 2010). Hal ini tidak menutup kemungkinan akan meningkatkan laju penyebaran dan perkembangan virus AI di tempat tersebut (Amonsin et al., 2008). Setelah terjadi taransaksi jual beli maka unggas akan menyebar ke berbagai kabupaten lain di seluruh Bali melalui perantara pembeli (Siahaan et al., 2014). Mobilitas unggas yang tinggi memungkinkan terjadinya rekombinasi serta mutasi virus AI di pasar (WHO, 2006). Berdasarkan hal tersebut maka perlu dilakukan pemeriksaan titer antibodi ayam buras di pasar unggas untuk mengetahui kondisi penyebaran penyakit AI di pasar hewan. Jika seroprevalensi AI di pasar hewan dalam suatu waktu tertentu berubah maka kemungkinan besar juga terjadi perubahan di peternakan sekitarnya (Siahaan et al., 2014).

Penelitian ini bertujuan untuk mendeteksi antibodi terhadap virus AI subtipe $\mathrm{H} 5 \mathrm{~N} 1$ pada ayam buras yang dijual di Pasar Beringkit dan Pasar Galiran, Bali. Deteksi antibodi virus AI subtipe H5N1 dilakukan didengan uji serologi hambatan hemaglutinasi (haemaglutination inhibition $=\mathrm{HI}$ ). Pemeriksaan serologi dilakukan di Balai Besar Veteriner Denpasar, Bali. Penelitian ini dilakukan selama 4 bulan di lapangan sejak bulan Oktober 2019 sampai Januari 2020.

\section{Metode dan Metode}

\section{Pengambilan Sampel}

Penelitian dilakukan denganmetode purposive sampling. Ayam buras untuk sampel berumur lebih dari 3 bulan dan belum pernah di vaksin AI subtipe H5N1. Sampel diambil sebanyak 4 kali per pasar dengan jarak pengambilan dua minggu sekali. Jumlah ayam yang digunakan untuk sampel adalah sebagai berikut: sebanyak tiga ekor ayam dijadikan sampel dari pedagang menjual minimal 6-10 ekor ayam buras. Sampel darah diambil 
melalui vena brachialis yang sebelumnya telah didesinfeksi menggunakan kapas beralkohol 70\% $1,5 \mathrm{ml}$ dengan menggunakan disposable syringe volume $3 \mathrm{ml}$. Setelah darah masuk ke spuit, disisakan ruang kosong pada spuit, kemudian spuite ditempatkan di dalam cool box dengan posisi horizontal (Darmawi et al., 2013).

\section{Pemisahan Serum}

Sampel darah yang baru diambil dibiarkan satu sampai dua jam agar serumnya keluar kemudian ditampung dalam tabung mikro. Serum selanjutnya disentrifus dengan kecepatan 2500 rpm selama 10 menit. Serum dipisahkan dari bekuan darah dan ditampung dengan tabung mikro steril kemudian dimasukkan ke dalam penangas air bersuhu $56^{\circ} \mathrm{C}$ dan didiamkan selama 30 menit (Kencana et al., 2016).

\section{Uji Serologi}

\section{Pembuatan suspensi eritrosit 1\%}

'Suspensi sel darah merah ayam 1\% disiapkan dengan cara: sebanyak $2,5 \mathrm{~mL}$ darah ayam yang berisi antikoagulan selanjutnya dicuci dengan cara ditambahkan $5 \mathrm{~mL}$ Phosphat Buffered Saline (PBS) pH 7,2 lalu dihomogenkan perlahan-lahan agar tidak rusak, selanjutnya darah disentrifuse engan kecepatan 2500 rpm selama 15 menit. Buffy coat dan supernatan dipisahkan dari endapan eritrosit. Eritrosit dicuci sebanyak tiga kali, endapan eritrosit hasil pencucian dipisahkan lalu diencerkan hingga 1\% dalam larutan PBS (OIE, 2012).

\section{Uji Hemaglutinasi (HA)}

Uji hemaglutinasi yang digunakan adalah teknik mikrotiter. Sebanyak 0,025 mL Phosphat buffer saline (PBS) ditambahkan kedalam setiap sumuran plat mikro dengan menggunakan pipet mikro. Sebanyak $0,025 \mathrm{~mL}$ suspensi antigen AI subtipe H5N1 standar dari Pusvetma, ditambahkan pada sumuran pertama. Pengenceran berseri berkelipatan dua dimulai dari sumuran ke-1, dengan menggunakan mikropipet diambil sebanyak $0,025 \mathrm{~mL}$ campuran tadi lalu diencerken berseri sampai sumuran ke-11, kemudian pada sumuran nomor 11 suspensi ini dibuang. Selanjutnya PBS ditambahkan sebanyak 0,025 mL kedalam setiap sumuran plat mikro. Sel darah merah unggas $1 \%$ ditambahkan sebanyak 0,025
$\mathrm{mL}$ ke dalam setiap sumuran plat mikro kemudian digoyang-goyangkan menggunakan pengayak mikro selama kurang lebih 15 detik. Plat mikro dibiarkan pada suhu ruangan selama 30 menit sambil diamati terjadinya hemaglutinasi. Reaksi positif pada uji HA ditandai dengan adanya bentukan butiran seperti pasir pada sumuran plat mikro akibat dari reaksi haemaglutinasi. Pembacaan titer HA dilakukan dengan cara memiringkan plat mikro pada kemiringan $\geq 45^{\circ}$ (Kencana et al., 2015) dan penentuan titer HA dilihat dari pengenceran antigen tertinggi yang masih dapat menghaemaglutinasi sel darah merah secara sempurna. Titer HA yang digunakan pada uji HI adalah 4 unit HA (OIE, 2012).

\section{Uji Hambatan Hemaglutinasi (HI)}

Sebelum dilakukan uji, serum dipanaskan terlebih dahulu pada suhu $56^{\circ} \mathrm{C}$ selama 30 menit Antigen 4 unit HAjuga disiapkan untuk uji HI. Setelah semua bahan siap selanjutnya sebanyak 0,025 mL PBS dimasukan ke setiap sumuran plat mikro. Sumuran pertama diisi dengan 0,025 $\mathrm{mL}$ serum kemudian diencerkan secara berseri kelipatan dua mulai dari sumuran ke-1 sampai ke-10 dengan pengencer mikro dan dari sumuran nomor 10 suspensi dibuang sebanyak $0.025 \mathrm{~mL}$. Masing-masing sumuran plat mikro ditambahkan dengan $0,025 \mathrm{~mL}$ suspensi antigen AI 4 unit HA mulai dari sumuran nomor 1 sampai nomor 11. Plat mikro goyang-goyangkan selama kurang lebih 15 detik dengan mikroshaker kemudian dibiarkan selama 30 menit pada suhu ruangan. Suspensi sel darah merah $1 \%$ ditambahkan ke dalam sumuran ke-1 sampai ke-12 sebanyak 0,025 ml lalu diayak kembali selama kurang lebih 15 detik. Plat mikro kemudian diinkubasikan pada suhu kamar selama 30 menit sambil diamati. Pembacaan hasil uji HI dilakukan apabila pada sumuran nomor 11 sudah tampak adanya aglutinasi eritrosit dan pada sumuran nomor 12 terlihat endapan eritrosit. Titer HI dibaca dengan cara memiringkan plat mikro 45 derajat dan melihat ada atau tidaknya endapan sel darah merah yang turun (tear-shaped) sebagai tanda uji HI positif. Titer HI ditentukan dengan cara melihat pengenceran serum tertinggi yang masih mampu menghambat aglutinasi eritrosit $1 \%$ (OIE, 2012). 


\section{Analisis Data}

Data titer antibodi HI dari sampel serum ayam buras dianalis dengan uji statistik Non- parametrik Chi-Square menggunakan software Statistical Product dan Service Solution (SPSS) (Sampurna dan Nindhia, 2019). Seroprevalensi AI dihitung dengan rumus:

Seroprevalensi $\%=\frac{\text { Jumlah serum }(+) \text { hasil uji x } 100 \%}{\text { Jumlah keseluruhan sampel }}$

\section{Hasil Dan Pembahasan}

Sebanyak 120 sampel serum yang di uji HI, 6 sampel diantaranya positif dengan titer $2^{4}$ dan $2^{6}$ HI Unit. Persentase uji HI sampel serum ayam buras yang positif dan negatif Avian Influenza H5N1 di Pasar Beringkit dan Pasar Galiran dimuat pada Tabel 1.

Tabel 1. Persentase uji HI sampel serum ayam buras berdasarkan waktu dan lokasi pengambilan

\begin{tabular}{ccccc}
\hline \multirow{2}{*}{$\begin{array}{c}\text { Waktu } \\
\text { Pengambilan }\end{array}$} & \multicolumn{3}{c}{ PASAR } \\
\cline { 2 - 5 } Sampel & \multicolumn{2}{c}{$(60)$} & \multicolumn{2}{c}{$\begin{array}{c}\text { Pasar Galiran } \\
(60)\end{array}$} \\
\cline { 2 - 5 } & Positif (+) & Negatif (-) & Positif (+) & Negatif (-) \\
\hline \multirow{2}{*}{1} & $6,7 \%$ & $93,3 \%$ & $0,0 \%$ & $100,0 \%$ \\
2 & $0,0 \%$ & $100,0 \%$ & $26,7 \%$ & $73,3 \%$ \\
3 & $6,7 \%$ & $93,3 \%$ & $0,0 \%$ & $100,0 \%$ \\
Rataan & $0,0 \%$ & $100,0 \%$ & $0,0 \%$ & $100,0 \%$ \\
\hline
\end{tabular}

Hasil uji HI sampel pada pengambilan pertama di Pasar Beringkit 6,7\% (1/15) positif antibodi virus AI-H5N1 sedangkan sampel asal Pasar Galiran negatif $(0,0 \%)$. Pengambilan periode kedua hasilnya negatif $(0,0 \%)$ sampel Pasar Beringkit sedangkan sampel Pasar Galiran hasilnya $26,7 \% \quad(4 / 15)$ positif. Uji sampel pengambilan periode ketiga di Pasar Beringkit diperoleh 6,7\% (1/15) positif sedangkan di Pasar Galiran semuanya negatif. Hasil uji sampel pengambilan periode keempat di Pasar Beringkit dan di Pasar Galiran semuanya negatif antibodi AI-H5N1.

Hasil uji statistika Non-Parametrik dengan Chi-Square menunjukkan bahwa seroprevalensi infeksi virus AI-H5N1 di Pasar Beringkit dan Pasar Galiran pada ayam buras untuk empat kali pengambilan sampel tidak berbeda nyata $(\mathrm{P}>0,05$ / $\mathrm{P}=0,402$ ) seperti dimuat pada Tabel 2.
Tabel 2. Seroprevalensi infeksi virus Avian Influenza pada empat kali pengambilan

\begin{tabular}{ccccc}
\hline $\begin{array}{c}\text { Waktu } \\
\text { Pengambilan }\end{array}$ & $\begin{array}{c}\text { Pasar } \\
\text { Beringkit }\end{array}$ & $\begin{array}{c}\text { Pasar } \\
\text { Galiran }\end{array}$ & $\begin{array}{c}\text { Nilai Chi- } \\
\text { Square }\end{array}$ & $\begin{array}{c}\text { Asymp.sig } \\
\text { (tailed-2) }\end{array}$ \\
\hline 1 & $6,7 \%$ & $0,0 \%$ & & \\
2 & $0,0 \%$ & $26,7 \%$ & & \\
3 & $6,7 \%$ & $0,0 \%$ & 0,702 & 0.402 virus \\
4 & $0,0 \%$ & $0,0 \%$ & & \\
\hline Rataan & $3,3 \%$ & $6,7 \%$ & & \\
\hline
\end{tabular}

Rataan titer antibodi HI sampel serum ayam buras yang diambil dari Pasar Beringkit dan Pasar Galiran dimuat pada Tabel 3.

Tabel 3. Hasil rataan titer antibodi HI $(\log 2)$ ayam buras di Pasar Beringkit dan Galiran

\begin{tabular}{|c|c|c|}
\hline \multirow{2}{*}{$\begin{array}{l}\text { Waktu } \\
\text { Pengambilan } \\
\text { Sampel }\end{array}$} & \multicolumn{2}{|c|}{ PASAR } \\
\hline & Pasar Beringkit (60) & Pasar Galiran (60) \\
\hline 1 & 2,00 & 1,75 \\
\hline 2 & 1,33 & 3,67 \\
\hline 3 & 4,00 & 0,00 \\
\hline 4 & 0,00 & 0,00 \\
\hline Rataan & $2,00 \pm 1,09$ & $2,57 \pm 1,60$ \\
\hline
\end{tabular}

Avian Influenza (AI) adalah penyakit virus pada unggas, termasuk ayam dan unggas liar yang disebabkan oleh virus influenza tipe A subtipe H5N1 (OIE, 2015) yang sangat mematikan. Di Asia, virus AI subtipe $\mathrm{H} 5 \mathrm{~N} 1$ termasuk virus strain HPAI. Bentuk gejala klinis akibat infeksi virus HPAI ditandai dengan angka kematian hampir $100 \%$ pada unggas terutama ayam buras dan ras dengan atau tanpa menunjukkan gejala klinis sebelum terjadi kematian (Hewajuli dan Dharmayanti, 2008). Ayam yang terserang virus HPAI umumnya tidak menunjukkan gejala klinis melainkan langsung mati mendadak. Virus penyakit AI memiliki aktivitas hemaglutinasi dari protein Hemaglutinin (HA) untuk mengikat sel darah merah unggas $1 \%$, sehingga dapat dideteksi dengan uji HA/HI. Reaksi positif uji HI karena adanya ikatan antara antigen dengan antibodi spesifik yang homolog ditandai dengan endapan sel darah merah $1 \%$ pada dasar plat mikro (Kencana, 2012).

Uji HA dilakukan untuk mengetahui adanya antigen terhadap virus AI. Sedangkan uji HI dilakukan untuk mengetahui titer antibodi spesifik 
dalam serum terhadap virus AI (Mahardika et al., 2016). Tujuan pemanasan serum sesaat sebelum dilakukan uji HI adalah untuk menghilangkan faktor penghambat nonspesifik yang terkandung dalam serum agar tidak mengganggu hasil uji HI (Kencana et al., 2015). Adanya faktor penghambat nonspesifik dalam serum dapat mengganggu spesifitas uji HI sehingga menghasilkan nilai titer yang salah (false negative) (WHO, 2014).

Berdasarkan hasil uji HI titer antibodi terhadap virus HPAI subtipe H5N1 dari 120 sampel serum ayam buras yang diambil di Pasar Beringkit dan Pasar Galiran didapatkan titer antibodi spesifik dengan kisaran $2^{1} \mathrm{HI}-2^{6} \mathrm{HI}$ unit. Hasil uji HI tersebut menunjukkan 6 sampel positif $(6 / 120)$ mengandung antibodi terhadap virus HPAI subtipe H5N1 dengan sebaran titer $2^{4}-2^{6}$ HI unit. Pada Tabel.3 terlihat rata-rata nilai titer antibodi tergolong rendah pada kedua pasar, menunjukkan ayam buras yang di jual banyak yang tidak memiliki antibodi protektif atau antibodi yang ada tidak dapat memberikan proteksi terhadap serangan virus AI. Hal ini dikarenakan ayam buras yang di jual di Pasar Beringkit dan Pasar Galiran tidak pernah di vaksinasi AI. Adanya titer antibodi yang sangat rendah kemungkinan disebabkan karena infeksi alami dari lingkungan yang terkontaminasi. Sementara untuk nilai titer antibodi yang tinggi tersebut diduga diperoleh dari sistem pertahanan tubuh yang merespon paparan virus AI secara terus menerus dari lingkungan sehingga terbentuk antibodi dalam tubuh unggas secara alami (Elfidasari et al., 2014).

Titer antibodi protektif adalah tingkat titer antibodi yang menunjukkan kekebalan hewan terhadap suatu infeksi. Titer antibodi ayam dikategoikan protektif terhadap serangan AI apabila titer antibodi $\geq 2{ }^{4} \mathrm{HI}$ unit (OIE, 2015). Untuk kategori titer tidak protektif $<2^{4}$ (Direktorat Jenderal Peternakan, 2005). Titer antibodi $>2^{4} \mathrm{HI}$ unit dapat memberikan proteksi terhadap penyakit AI sekitar $75 \%$, sedangkan nilai titer antibodi kisaran $2^{6}-2^{8} \mathrm{HI}$ unit dapat memberikan tingkat proteksi 100\% (Swayne, 2005). Kondisi titer antibodi ayam tidak akan selamanya protektif, setelah beberapa periode waktu, titer antibodi akan menurun dan kecepatan penurunan titer antibodi ini dipengaruhi oleh tantangan antigen penyakit maupun kondisi ternaknya (Sianita et al., 2011). Selain itu variasi titer antibodi dapat dipengaruhi oleh beberapa kondisi diantaranya kesehatan ayam, jumlah virus yang menginfeksi, dan perbedaan waktu infeksi (Bernadeta et al., 2015). Mekanisme imunitas dapat dipicu apabila dirangsang oleh paparan dosis virus yang cukup. Lamanya virus menginfeksi ayam juga mempengaruhi titer antibodi. Hewan yang baru saja terpapar virus (jangka waktu pemaparan singkat) akan menunjukkan nilai titer yang rendah, karena jumlah virus masih sedikit sehingga hewan tidak mampu menghasilkan antibodi dalam jumlah yang cukup tinggi (Darmawi et al., 2012).

Mahardika et al. (2016) menyatakan bahwa uji HI pada suatu serum dengan titer antibodi 4 unit HI $\left(2^{2}\right)$ menunjukkan hasil positif rendah. Titer antibodi $2^{2} \mathrm{HI}$ unit dianggap positif dengan titer antibodi yang sangat rendah karena sampel diambil dari ayam buras yang tidak divaksinasi (Suryana, 2005). Namun, dalam OIE, (2015) titer antibodi $2^{1} \mathrm{HI}$ unit sampai $2^{2} \mathrm{HI}$ unit dianggap dubius. Apabila menggunakan antigen 4HA unit, hasil uji dikatakan positif apabila titer antibodinya $\geq 2{ }^{4} \mathrm{HI}$ unit. Sementara jika menggunakan pengenceran antigen 8 HA unit, hasil uji dikategorikan positif apabila titer antibodi $\geq 2^{3} \mathrm{HI}$ unit.

Ayam buras yang tidak memiliki antibodi terhadap AI karena tidak ada paparan virus AI dalam tubuhnya. Berdasarkan hasil pemeriksaan serologiHI, besarnyatiterantibodiinimenunjukkan bahwa ayam buras yang di jual di Pasar Beringkit dan Pasar Galiran tampaknya pernah terinfeksi oleh virus AI meskipun titer antibodinya rendah. Antibodi yang terdeteksi memiliki titer rendah $<2^{4} \mathrm{HI}$ unit, bersifat tidak protektif terhadap virus AI (OIE, 2000). Titer antibodi ayam buras pada penelitian ini sebagian besar berada pada kisaran $2^{2} \mathrm{HI}$ unit yang mana titer tersebut bersifat tidak protektif.

Sampel diambil dari ayam buras yang berumur 3 bulan keatas sehingga maternal antibodi sudah tidak ada, dan untuk melihat terjadinya infeksi pada ayam buras tersebut. Faktor-faktor yang dapat menyebabkan titer antibodi rendah yaitu ketika ayam buras terinfeksi virus HPAI dengan jumlah antigen sedikit sehingga tubuh kurang mampu membentuk antibodi (Darmawi et al., 2013). Selain itu, kemungkinan karena ayam sudah lama terinfeksi alami sehingga titer antibodinya 
sudah menurun. Ketika ayam buras tidak memiliki antibodi protektif akan dapat terinfeksi virus HPAI-H5N1 (Yuliantari et al., 2018).

Titer antibodi yang rendah pada penelitian ini dapat juga disebabkan karena ayam buras tidak pernah divaksinasi dengan vaksin yang mengandung antigen dari virus AI subtipe H5N1. Ayam buras yang tidak memiliki antibodi atau titer antibodinya yang rendah sangat berisiko terhadap paparan virus HPAI subtipe H5N1 karena dapat menimbulkan kematian 100\%. Di Kabupaten Tabanan virus HPAI subtipe H5N1 masih ditemukan pada ayam buras tidak divaksinasi (Kencana et al., 2018). Kecamatan Marga lokasinya relatif dekat dengan Pasar Beringkit. Hasil wawancara dengan pedagang ayam buras di Pasar Beringkit saat pengambilan sampel bahwa mereka mendapatkan ayam buras juga dari pedagang ayam asal Kecamatan Marga.

Hasil penelitian menunjukkan seroprevalensi penyakit AI subtipe $\mathrm{H} 5 \mathrm{~N} 1$ pada ayam buras yang di jual di Pasar Beringkit sebanyak 3,3\% (2/60) sedangkan di Pasar Galiran 6,7\% (4/60). Secara keseluruhan seroprevalensi di kedua pasar diperoleh sebesar 5,0\%, lebih kecil dibandingkan dengan seroprevalensi di Bali tahun 2017 sebanyak 6,6\% (BBVet, 2018). Perbedaan angka seroprevalensi AI di Pasar Beringkit dan Galiran dapat dipengaruhi oleh faktor kondisi ayam buras yang dijual di pasar. Tingginya permintaan pasar pada saat tertentu memungkinkan para pedagang dan pengepul mendatangkan ayam buras dari daerah lain termasuk pula dari luar Bali (Disnak, 2009). Selain itu ada banyak faktor lain yang mempengaruhi perbedaan seroprevalensi AI diantaranya musim, migrasi burung liar, perbedaan manajemen peternakan asal unggas, keadaan lingkungan yang memungkinkan adanya kontak dengan itik yang merupakan reservoir virus AI dan unggas lain, daya tahan tubuh unggas, dan populasi ternak di pasar unggas dan peternakan (Saif, 2006).

Pendistribusian unggas terjadi dari berbagai peternakan ke Pasar Unggas Beringkit dan Galiran dilakukan langsung oleh peternak tanpa diperantarai oleh pengepul ayam. Sementara pengepul bertugas untuk membawa unggas dari berbagai peternakan dan mengantarkannya ke Pasar Unggas. Para peternak juga membeli bibit ayam buras di pasar unggas Beringkit dan Galiran sehingga terjadi kontak yang saling berkesinambungan di pasar. Pada saat pendistribusian unggas kemungkinan terjadi penyebaran virus AI dari peternakan ke pasar unggas Beringkit dan Galiran atau sebaliknya (Disnak, 2009). Peristiwa tersebut dapat diperparah lagi oleh manajemen yang buruk, baik di pasar, peternakan, maupun kendaraan pasar yang tidak didesinfeksi secara rutin yang dapat meningkatkan kemungkinan virus AI berkembang dan menyebar (Widyastuti et al, 2008). Perlakuan terhadap ternak ayam buras di pasar misalnya berjubel dalam satu keranjang akan dapat mempengaruhi tingkat stress ayam yang juga turut berpengaruh terhadap infeksi virus AI subtipe H5N1. Stress pada ternak menurunkan sistem kekebalan tubuh sehingga infeksi menjadi lebih parah (Damanik et al., 2013).

Siahaan et al. (2014) menyebutkan bahwa tingkat biosekuriti, sanitasi lingkungan, kesadaran higienis manusia, program vaksinasi, maupun pengawasan ternak berpengaruh terhadap infeksi AI. Tindakan pencegahan penularan virus AI dari itik ataupun ayam melalui pasar dapat dilakukan dengan cara regulasi pasar unggas agar tidak mencampurkan berbagai jenis unggas dalam suatu lokasi. Pembersihan kandang atau keranjang tempat menampung ayam buras saat dipasarkan juga perlu dilakukan untuk menghilangkan penyebaran sekunder virus AI. Pembersihan kandang dilakukan dengan menggunakan air secara berkala dengan frekuensi yang berbeda di antara masingmasing pemilik. Material seperti peralatan dan kandang yang tidak didesinfeksi secara berkala memungkinkan virus AI mampu bertahan hidup dalam kurun waktu yang lebih lama. Penerapan biosekuriti yang ketat seperti penggunaan desinfektan serta program vaksinasi merupakan faktor-faktor yang berperan untuk meminimalkan penyebaran virus AI ke lingkungan (Hewajuli et al., 2014)

Berdasarkan hasil analisis data uji HI dari sampel serum ayam buras yang di peroleh menunjukkan bahwa virus AI subtipe H5N1 masih bersirkulasi di Pasar Beringkit dan Galiran. Meskipun data hasil survey seroprevalensi terhadap penyakit AI menunjukkan nilai positif di Pasar Beringkit dan Pasar Galiran, namun data ini tidak dapat digunakan sebagai acuan untuk pelaksanaan 
monitoring dan evaluasi dalam jangka waktu yang lama. Hal ini dikarenakan survey lapangan hanya dilakukan dalam satu kali penelitian, sementara virus AI akan selalu mengalami dinamika setiap waktu. Hal ini menyebabkan hasil penelitian sekarang belum tentu sama dengan kondisi lapangan pada waktu berikutnya. Oleh karena itu perlu dilakukan pemantauan terhadap virus AI subtipe H5N1 di Pasar Beringkit dan Pasar Galiran secara periodik dalam jangka waktu panjang agar munculnya virus AI subtipe H5N1 ganas dapat terdeteksi secara dini.

\section{Kesimpulan}

Disimpulkan bahwa seroprevalensi penyakit AI subtipe H5N1 pada ayam buras di Pasar Beringkit sebesar 3,3\% dan di Pasar Galiran sebesar $6,7 \%$ dengan rata- rata seroprevalensi di kedua pasar sebesar 5,0\% yang secara statistik tidak berbeda nyata. Hasil tersebut menunjukkan bahwa virus avian influenza masih endemis di Bali, dan bersirkulasi di Pasar Beringkit dan Pasar Galiran, Bali. Mengingat proporsi titer antibodi yang diuji dengan antigen dari virus AI subtipe H5N1 pada ayam buras yang dijual di Pasar Beringkit dan Galiran termasuk kategori tidak protektif maka perlu dilakukan vaksinasi pada ayam buras. Managemen pasar perlu diperbaiki untuk mengurangi resiko penularan dan penyebaran virus AI pada hewan dan manusia.

\section{Ucapan Terima Kasih}

Penulis mengucapkan terima kasih kepada Balai Besar Veteriner Denpasar yang telah memberikan fasilitas penelitian serta telah memberikan kepercayaan terhadap penulis dan FKH Udayana dalam melakukan kerjasama terkait surveilans rutin terhadap Virus Avian Influenza subtipe H5N1.

\section{Daftar Pustaka}

Amonsin, A., Choatrakol, C., Lapkuntod, J., Tantilertcharoen, R., Thanawongnuwech, R., Suradhat, S., Suwannakarn, K., Theamboonlers, A. P., dan Yong. 2008. Influenza Virus (H5N1) in Live Bird Markets dan Food Markets, Thaildan. Emerging Infectious Diseases. 14 (11): 1739-1742.
Balai Besar Veteriner. 2018. Laporan Tahunan Balai Besar Veteriner Denpasar Tahun 2017. Direktorat Jenderal Peternakan

Bernadeta, E., Yuanita, I., dan Silitonga, L. 2015. Deteksi Antibodi Terhadap Virus Avian Influenza pada Ayam Buras di Peternakan Rakyat Kota Palangka Raya. Jurnal Ilmu Hewani Tropika. 4 (1): 22-26.

Elfidasari, D., Puspitasari, R, L., dan Frisa, A. 2014. Deteksi Antibodi Akibat Paparan Virus AI Subtipe H5N1 pada Unggas Air Domestik di Sekitar Cagar Alam Pulau Dua. Jurnal Al- Azhar Indonesia Seri Sains dan Teknologi. 2(4): 260-269.

Damanik, E. G., Kencana, G. A. Y., dan Mahardika, I. G. N. K. 2013. Seroprevalensi Penyakit Avian Influenza pada Itik di Kabupaten Klungkung. Buletin Veteriner. 5(2): 139146.

Darmawi., Manaf, Z. H., Darniati., Fakhrurrazi., Abrar M., dan Erina. 2012. Deteksi Antibodi Serum Terhadap Virus Avian influenza pada Ayam Buras. Agripet. Vol 12 (1): 23-27

Darmawi. D., Dewi, M., Fakhrurrzi., Abrar, M., dan Erina. 2013. Seroprevalensi Avian Influenza H5N1 pada Unggas di Kabupaten Aceh Utara. Agripet. 13(2): 21-25.

Dinas Peternakan Provinsi Bali. 2009. Panduan Pengendalian Penyakit hewan Menular Strategis.

Dinh, P. N., Long, H. T., Tien, N. T. K., Hien, N. T., Mai, L. T. Q., Phong, H., Tuan, L. V., Tan,

H. V., Nguyen, N. B., Tu, P. V., and Phuong, N. T. M. 2007. Risk Factor for Human Infection with Avian Influenza A H5N1, Vietnam. Emerging Infect Dis. 13 (9).

Direktorat Jenderal Peternakan. 2005. Manual Standar Kesehatan Hewan. Edisi Pedoman Surveilans dan Monitoring Avian Influenza di Indonesia. Dapartemen Pertanian, Jakarta.

Hartawan, D. H. W. 2011. Deteksi Avian Influenza di Pasar Unggas Berisiko Tinggi di Propinsi Bali pada Musim dan Jumlah Permintaan Unggas yang Berbeda (tesis). Yogyakarta. Universitas Gajah Mada. 
Hewajuli, D. A., dan Dharmayanti, N. I. P. I. 2008. Karakterisasi dan Identifikasi Virus Avian Influenza (AI). Wartazoa. 18(2): 86-100.

Hewajuli, D. A., dan Dharmayanti, N. I. P. I. 2014. Identifikasi Flu Burung H5N1 pada Unggas di Sekitar Kasus Flu Burung pada Manusia Tahun 2011 di Bekasi. Jurnal Veteriner. 15(1): 68-78. ISSN: 1411-8327.

Kandun, I. N. 2006. Pengendalian penyakit flu burung di Indonesia. Seminar ilmiah Avian Influenza- A global new life threatening disease, UGM.

Kencana, G. A. Y. 2012. Penyakit Virus Unggas. Udayana University Press. ISBN: 978-6027776-01 -2.

Kencana, G. A. Y., Suartha, I. N., Paramita, N. M. A. S., dan Handayani, A. N. 2016. Vaksin Kombinasi Newcastle Disease dengan Avian Influenza Memicu Imunitas Protektif pada Ayam Petelur terhadap Penyakit Tetelo dan Flu Burung. Jurnal Veteriner. 17(2): $257-264$.

Kencana, G. A. Y., Suartha, I. N., Simbolon, M. P., Handayan,i A. N., Ong, S., Syamsidar, dan Kusumastuti, A. 2015. Respons Antibodi terhadap Penyakit Tetelo pada Ayam yang Divaksin Tetelo dan Tetelo-Flu Burung. Jurnal Veteriner. 16(2): 283-290.

Kencana, G. A. Y., Suartha, I. N., dan Kardena, I. M. 2018. Avian Influenza Virus-H5N1 Is Circulating Among Backyard Chiken in Marga District, Tabanan Regency, Bali. Proc. of the 20th FAVA CONGRESS \& the 15th KIVNAS PDHI, Bali.

Kumala, W. 2005. Avian Influenza: Profil dan Penularannya pada Manusia. Universa Medicina. 24(4): 184-188.

Leung, Y. H. C., L. J., Zhang, C. K., Chow, C. L., Tsang, N. G., Chi-Fung, C. K., Wong, Y., Guan, J. S. M., and Peiris. 2007. Poultry Drinking Water Used for Avian Influenza Surveillance. Emerging Infectious Diseases. 13(9): 1380-1382.

Mahardika, I. G. N. K., Sibang, M., Suamba, M., Adnyana, K. A., Dewi, N. M. S., Meidiyanti, K. A., and Paulus, Y. A., 2004. Isolasi virus
Influenza pada ayam kampung di Bali. Jurnal Veteriner 5 (1): 35-45.

Mahardika, I. G. N. K., Astawa, I. N. M., Kencana, G. A. Y., Suardana, I. B. K., dan Sari, T. K. 2016. Teknik Lab Virus. Udayana University Press. Denpasar. ISBN: 978602-294-004-9.

Nguyen, D. C., Uyeki, T. M., Jadhao, S., Maines, T., Shaw, M., Matsuoka, Y., Smith, C., Rowe, T., Lu, X., Hall, H., Xu, H., Balish, A., Klimov, A., Tumpey, T. M., Swayne, D. E., Huynh, L. P. T., Nghiem, H. K., Nguyen, H. H. T., Hoang, L. T., Cox, N. J., and Katz, J. M. 2005. Isolation dan Characterization of Avian Influenza Viruses, Including Highly Pathogenic H5N1, from Poultry in Live Bird Markets in Hanoi, Vietnam, in 2001. $J$ Virol. 79(7): 4201-4212.

Office International des Epizooties (OIE). 2000. OIE Manual of Standards for Diagnostic Test dan Vaccines, 4th ed. Diakses tanggal 3 Maret 2020.

Office International des Epizooties (OIE). 2012. Manual of Diagnostic Test and Vaccines for Terresterial Animal Chapter. Capter 2.3.14. Newcastle Disease. Hlm. 1-9 www.oie.int. Diakses tanggal 7 Juli 2020.

Office International des Epizooties (OIE). 2015. Chapter 2.3.4. Avian Influenza (Infection with Avian Influenza Viruses). OIE Terrestrial Manual: $1-23$.

Putra, I. G. N. N., Dewi, N. M. R. K., Suartha, I. N., dan Mahardika, I. G. N. K. 2013. Dinamika Seroprevalensi Virus Avian Influenza H5 pada Itik di Pasar Unggas Beringkit dan Galiran. Jurnal Ilmu dan Kesehatan Hewan. 1(2): 70-75.

Saif, M. C. 2006. Avian Influenza. An Internal Report for the College of Food, Agricultural, dan Environmental Sciences.

Siahaan, L. L., Suartha, I. N., dan Mahardika, I. G. N. K. 2014. Seroprevalensi Avian Influenza pada Itik di Pasar Hewan Beringkit dan Peternakan di Badung. Indonesia Medicus Veterinus. 3(2): 147-154. ISSN: 2301-7848.

Sianita, N., Hasan, Z., dan Kusriningrum, R. 2011. Respon Antibodi dan Protektivitas 
pada Ayam Pasca Vaksinasi Menggunakan Vaksin ND Aktif LV12. Veterinaria Medika 4(2):129- 134.

Sampurna, I. P.,d an T. S. Nindhia. 2019. Biostatistika. Penerbit Puri Bagia. Genre Pendidikan.

Diterbitkan Online melalui nulisbuku.com/viewprofile/90381/1\%20Putu-Sampurna

Suartha, I. N., Antara, I. M. D., Wiryana, I. K. S., Sukada, I. M., Wirata, I. W., Dewi, N. M. R. K., dan Mahardika, I. G. N. K. 2010. Peranan Pedagang Unggas dalam Penyebaran Virus Avian Influenza. Jurnal Veteriner. 11(4): 220-225.

Suryana, N. 2005. Isolasi dan Identifikasi Virus Avian Influenza dari Ayam Asal Peternakan di Jawa Timur. Prosiding Temu Teknis Nasional Tenaga Fungsional Pertanian 2005: 186- 190.

Susanti, R., Soejoedono, R. D., Mahardika, I. G. N. K., Wibawan, I. W. T., dan Suhartono, M. T. 2008. Filogenetik dan Struktur Antigenik Virus Avian Influenza Subtipe H5N1 Isolat Unggas Air. J Vet. 9(3): 99-106.

Swayne, D. 2005. Avian Influenza, Poultry Vaccines: a review. A ProMed-mail post (http://www.premedmail.org). Diakses tanggal 17 Maret 2020.

Widyastuti N. D. W., Basri, C., Naipospos, T. S. P., dan Bleich, E. G., 2008. Tinjauan Sistem Beternak Itik Secara Lepas di Indonesia dan Penilaian Implikasinya Terhadap Penyebaran AI Strain Highly Pathogenic (H5N1). KIVNAS 19th - 22th
World Health Organization (WHO). 2006. Geografical spread of H5N1 avian influenza in bird- update 28 Situation assessment dan implication for human health. www.who. intWHO. 2006. A Manual for Improving Biosecurity in the Food Supply Chain: Focusing on Live Animal Market. Public Health Intervention for Prevention dan Control of Avian Influenza. New Delhi.

World Health Organization (WHO). 2014. H5N1 highly Pathogenic Avian Influenza: Timeline of Major Event. Available at www.who.int. (Diakses pada tanggal 25 April 2020).

Wright, P. E., dan Webster, R. G. 2001. Orthomyxoviridae. In Fields Virology. 4th ed. Edited by Knipe DM, Howley PM, Griffin DE, Martin MA, Lamb RA, Roizman B, Straus SE, Lippincott Williams, dan Wilkins, Philadelphia, USA: 1533-1568.

Yuliantari, I. A. M., Kencana, G. A. Y., dan Kardena, I. M. 2018. Seroprevalensi Penyakit Flu Burung (Avian Influenza) pada Ayam Kampung di Kerta, Payangan, Gianyar, Bali. Indonesia Medicus Veteriner. 7(6): 689-698. 